\title{
Neurological Manifestaions in Acute Onset of Viral Gastroentritis
}

\section{Samileh Noorbakhsh ${ }^{1 *}$, Hamid Reza Monavari ${ }^{2}$ and Azardokht Tabatabaei ${ }^{3}$}

${ }^{1}$ Professor of Pediatric Infectious Diseases, Research Center of Pediatric Infectious, Diseases, Tehran University of Medical Sciences, Iran

${ }^{2}$ Research Center of Pediatric Infectious, Diseases, Tehran University of Medical Sciences, Iran

${ }^{3}$ Microbiologist, Research Center of Pediatric Infectious Diseases, Tehran University of Medical Sciences, Iran

\begin{abstract}
Back ground: AGE is one of the most common causes of morbidity and mortality in infants and children in developing countries with near 11,000 deaths per day in the world.

Objective: To evaluate the prevalence of neurological manifestations in acute onset of viral gastrointestinal.

Methods: A cross sectional/descriptive study performed upon 50 children admitted due to acute viral gastrointestinal infections in Department of pediatric Infectious Disease, Rasul Hospital, Tehran, Iran, 2010- 2011. Initially, a questionnaire was completed by an authorized physician for each cases (eg: age, gender, clinical signs, vomiting, diarrhea (type, time of onset, frequency) attending time from onset ,type of neurologic symptoms ,analysis of lab test (stool direct exams, biochemical parameters, stool culture, direct viral test in stool). All cases with bacterial or other known causes (except viral causes) for gastroenteritis, chronic diarrhea excluded from study. The studied cases were evaluated for existence of neurologic signs .Stool samples were searched for viral antigens (Rota \& Adeno virus) by Rapid immune chromatographic test. P-values less than 0.05 were considered statistically significant.

Results: Neurological manifestations observed in $16 \%$ of cases included seizure $12 \%$ aseptic meningitis $4 \%$, $20 \%$ of adenoviral, $13.5 \%$ of rota virus and $33.3 \%$ of bi-infection had neurologic signs, with no differences $(P=0.619)$. Mean age of cases had not significant difference between cases with and without neurologic manifestation. There was no significant association between neurological symptoms with age $(P=0.755)$, sex, virus type and attending time $(P>0.05)$.

Conclusions: This study indicated that viral agents, especially rota virus can be obtained from near $60 \%$ of studied cases. Adenovirus (20\%); Human Boca virus ( $8 \%$ ) and other (undiagnosed) viral infection were less common causes. Neurological symptoms including seizure or aseptic meningitis might observe in $16 \%$ of children especially in cases with co-infection rota and adenoviral infection (33.3\%) which is not related to age, sex and attending time. Rotavirus-associated encephalopathy described by some authors. Due to presence a safe and effective rotavirus vaccination, we prefer to routine usage of it as a public health priority in Iran. Further study is required to determine the role of rotavirus and other viral infection in diarrhea associated encephalopathy.
\end{abstract}

Keywords: Convulsion; Diarrhea; Viral gastroenteritis; Neurologic symptoms; Rota virus; Adeno virus; Human Boca Virus

\section{Introduction}

Acute gastroenteritis (AGE) known by vomiting, diarrhea and dehydration [1]. Acute diarrhea disease is the second cause of death among all infectious diseases in children younger than 5 years of age worldwide [2,3]. AGE is one of the most common cause of morbidity and mortality in infants and children in developing countries with near 11,000 deaths per day in the world $[4,5]$. Viral AGE is a major cause of morbidity in childhood and leaded to be hospitalized even in developed countries. Different types of viruses such as norovirus, rotavirus, astrovirus, adenovirus, enterovirus, parechovirus causes AGE diseases.

Rotavirus is a common cause of severe gastroenteritis in children $[1,2]$. There are increasing reports of cases in which patients who have seizures after an episode of rotavirus diarrhea have evidence of rotavirus in their CSF [3]. Although evidence suggesting that rotavirus is a cause of central nervous system squeal remains inconclusive [4-6]. Rotavirusassociated encephalopathy described by some authors. Nakagomi et al. study [7] determined the rotavirus antigen in acute phase sera from 5 of 8 children with rotavirus-associated encephalopathy, confirming antigenemia, but not in cerebrospinal fluid, failing to provide added evidence of invasion to the brain [7].

Enteric adenoviruses, i.e. adenovirus 40 (Ad40) and adenovirus 41 (Ad41), have been shown to be a substantial cause of pediatric gastroenteritis in various parts of the world and may be the second major causative agent of gastroenteritis after rotaviruses [1,2].

Human bocavirus $(\mathrm{HBoV})$ is a recently discovered virus of the family Parvoviridae, genus Bocavirus, as a new agent associated with respiratory tract infections (RTI) and AGEn children [8]. The range of seroprevalence is from $48 \%$ to $85 \%$ at the age of 4 years. The peak of $\mathrm{HBoV}$ is in winter months and is often found in coincidence with other pathogens. Some studies showed that $\mathrm{HBoV}$ is responsible for severe infections of the lower respiratory tract in small children but less data are available on the role of $\mathrm{HBoV}$ in gastroenteritis [7]. The frequency of HBoV differs between countries (Canada 1.5\%, Sweden 3.1\%, Australia

${ }^{*}$ Corresponding author: Samileh Noorbakhsh, Research Center of Pediatric linfectious Diseases, Tehran University of Medical Sciences, $4^{\text {th }}$ floor Hazrat Rasul Hospital, Niayesh Street, Satarkhan Avenue, Tehran, 14455 Islamic Republic of Iran, Tel: 098-21-66525328; Fax: 098-21-66516049; E-mail: Samileh_noorbakhsh@yahoo.com, S-noorbaqkhsh@tums.ac.ir

Received November 19, 2012; Accepted December 10, 2012; Published December 18, 2012

Citation: Noorbakhsh S, Monavari HR, Tabatabaei A (2013) Neurologica Manifestaions in Acute Onset of Viral Gastroentritis. J AIDS Clin Res 4: 189 doi:10.4172/2155-6113.1000189

Copyright: (c) 2013 Noorbakhsh S, et al. This is an open-access article distributed under the terms of the Creative Commons Attribution License, which permits unrestricted use, distribution, and reproduction in any medium, provided the original author and source are credited. 
Citation: Noorbakhsh S, Monavari HR, Tabatabaei A (2013) Neurological Manifestaions in Acute Onset of Viral Gastroentritis. J AIDS Clin Res 4: 189. doi:10.4172/2155-6113.1000189

5.6\%, and Japan 5.7\%, Germany $10.3 \%$ and Korea 11.3\%) [8-14] but its prevalence in Iran is unknown.

AGE is a common cause for hospital admission in Iranian children [11-16]. Rota virus antigen obtained from stool of AGE cases between $15-47 \%$ of hospitalized children with AGE, just in $12 \%$ of controls group. Adenovirus and astrovirus obtained from stool of Iranian children with AGE [11-21]. Saderi et al. reported the incidence of enteric adenoviruses in Iranian children. $6.7 \%$ of stool specimens contained enteric adenoviruses (3.3\% Ad40 and 3.4\% Ad41) and 2.0\% nonenteric adenoviruses [14]. In countries such as Iran, which rotavirus vaccination in not used knowledge of viral ethnological pathogens of AGE is very important in planning diarrhea disease control strategies [15-19]. It might be useful for future vaccine development in the region.

The object of the study was to determine the prevalence of neurological symptoms in children with acute onset of viral gastrointestinal.

\section{Methods and Materials}

A cross sectional descriptive study performed in pediatric Department of Rasul Hospital, Tehran, Iran between 2010 and 2011 upon 50 children admitted in pediatric ward due to acute viral gastrointestinal disease. The study was approved by the Ethical Committee in Research Center of Pediatric Infectious Diseases in Tehran University of Medical Sciences. The studied cases were evaluated by authorized physician for existence of neurologic signs by clinical exam and history of convulsion; association of neurological symptoms.

\section{Data collection}

Initially, a questionnaire was completed by an authorized physician for each cases (eg: age, gender, clinical signs vomiting, diarrhea type attending time, type of neurologic symptoms, analysis of lab test (stool direct exams, biochemical parameters, $\mathrm{CBC}$ stool culture, direct viral test in stool). All cases with bacterial or other known causes (except viral causes) for gastroenteritis excluded from study.

Stool samples were searched for viral antigens (Rota \& Adeno virus) by Rapid chromatographic test. All of samples were collected on viral

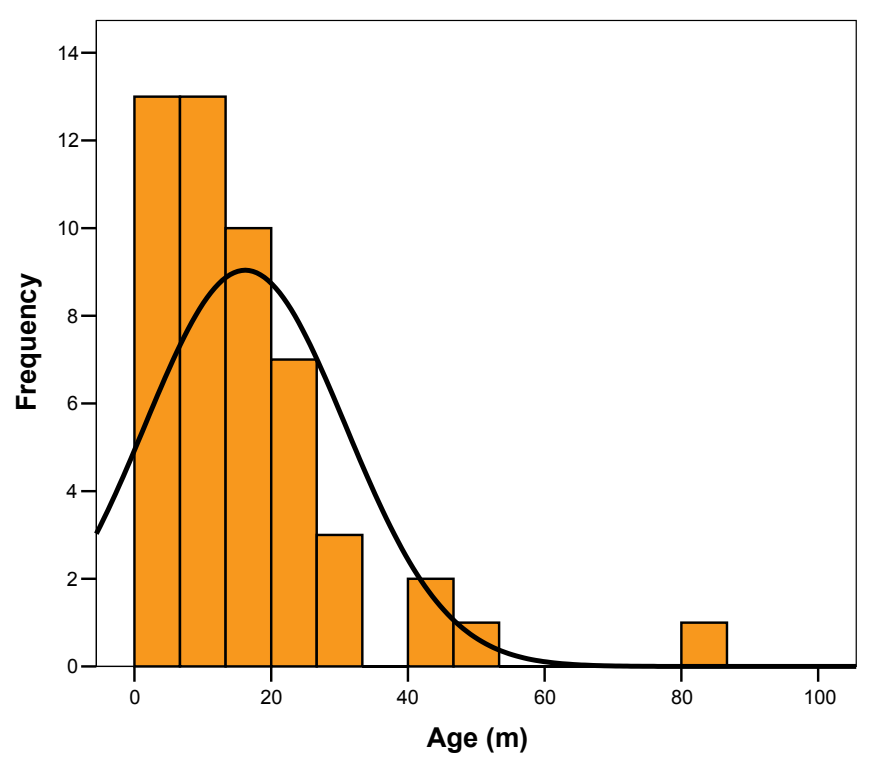

Figure 1: Age histogram of cases.

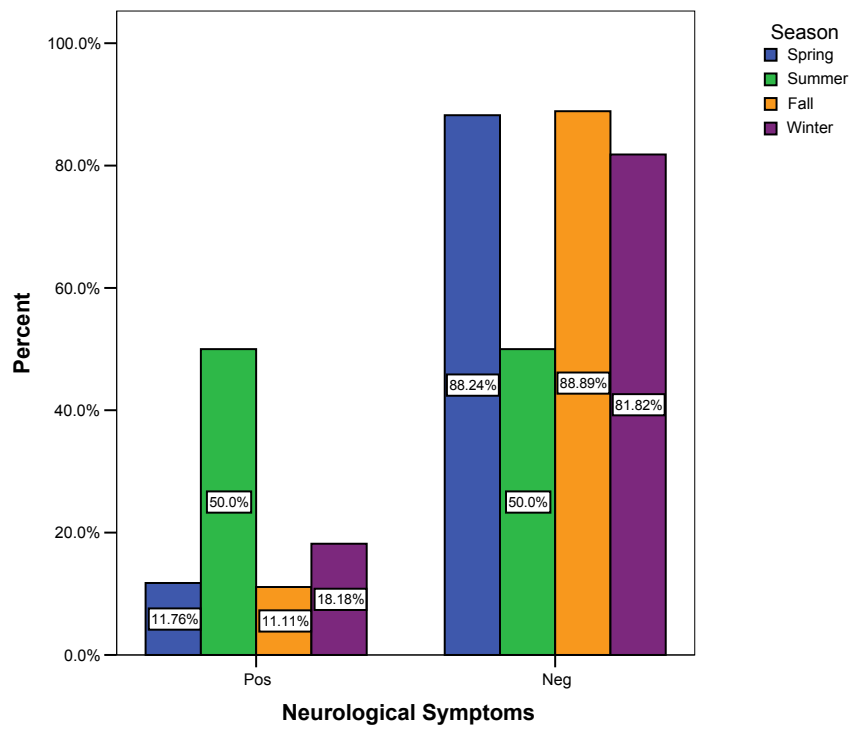

Figure 2: Seasonal distribution of cases with Neurologic symptoms.

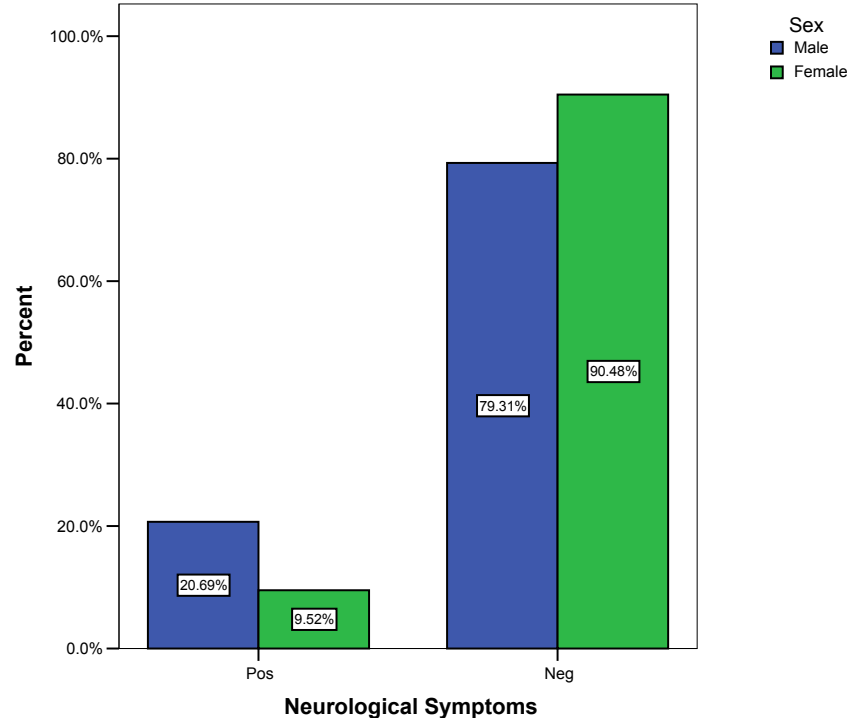

Figure 3: Comparison of neurologic symptoms between 2 sex.

transport media. $\mathrm{HBoV}$ was detected using Real-time PCRTaqMan method.

\section{Statistical analysis}

The student's $t$ test was used to determine significant in means for continuous variables. The mann whitney $u$ test and the chi-square test were used to compare groups. $p$-values less than 0.05 were considered statistically significant.

\section{Results}

50 children with acute onset gastroenteritis studied. Age, sex and seasonal distribution presented in figures 1-3 and Tables 1-3. Rotavirus infection diagnosed in $48 \%(24 / 50)$, Adenovirus in $20 \%(10 / 50)$ of cases, Human Boca virus was detected in $8 \%(4 / 50)$ and $6 \%(3 / 50)$ had co-infection with both virus (Adeno \& Rota virus). Unknown causes 


\begin{tabular}{|l|c|}
\hline Age $(\mathrm{M})$ & \\
\hline Mean & 16.20 \\
\hline Median & 12.50 \\
\hline Std. Deviation & 14.711 \\
\hline Minimum & 2 \\
\hline Maximum & 84 \\
\hline
\end{tabular}

Table 1: Age of cases

\begin{tabular}{|c|c|c|c|c|}
\hline & & \multicolumn{2}{|c|}{ Neurological Symptoms } & \multirow[b]{2}{*}{ Total } \\
\hline \multirow{5}{*}{ Season } & & Positive & Negative & \\
\hline & Spring & $\begin{array}{c}2 \\
11.8 \%\end{array}$ & $\begin{array}{c}15 \\
88.2 \%\end{array}$ & $\begin{array}{c}17 \\
100.0 \%\end{array}$ \\
\hline & Summer & $\begin{array}{c}1 \\
50.0 \%\end{array}$ & $\begin{array}{c}1 \\
50.0 \%\end{array}$ & $\begin{array}{c}2 \\
100.0 \%\end{array}$ \\
\hline & Fall & $\begin{array}{c}1 \\
11.1 \%\end{array}$ & $\begin{array}{c}8 \\
88.9 \%\end{array}$ & $\begin{array}{c}9 \\
100.0 \%\end{array}$ \\
\hline & Winter & $\begin{array}{c}4 \\
18.2 \%\end{array}$ & $\begin{array}{c}18 \\
81.8 \%\end{array}$ & $\begin{array}{c}22 \\
100.0 \%\end{array}$ \\
\hline \multicolumn{2}{|c|}{ Total } & $\begin{array}{c}8 \\
16.0 \%\end{array}$ & $\begin{array}{c}42 \\
84.2 \%\end{array}$ & $\begin{array}{c}50 \\
100.0 \%\end{array}$ \\
\hline
\end{tabular}

Table 2: Seasonal distribution of cases with Neurologic symptoms.

\begin{tabular}{|c|c|c|c|c|}
\hline \multirow{2}{*}{\multicolumn{2}{|c|}{}} & \multicolumn{2}{|c|}{ Neurological Symptoms } & \multirow{2}{*}{ Total } \\
\cline { 3 - 4 } & & Positive & Negative & \\
\hline \multirow{3}{*}{ Sex } & Male & 6 & 23 & 29 \\
& & $20.7 \%$ & $79.3 \%$ & $100.0 \%$ \\
\cline { 2 - 5 } & Female & 2 & 19 & 21 \\
\hline \multirow{2}{*}{ Total } & & $8.5 \%$ & $90.5 \%$ & $100.0 \%$ \\
\hline
\end{tabular}

Table 3: Comparision of neurologic symptoms between 2 sex.

for viral gastroenteritis were $12 \%(6 / 50)$.

The frequency of positive Human Boca virus was significantly lower than Adeno \& Rota virus ( $\mathrm{p}=0.0001) .16 \%$ of children had neurological symptoms included seizure in $12 \%$; aseptic meningitis in $4 \%$ (figures 2 and 3). Mean age of cases had not significant difference between cases with and without neurologic manifestation $(\mathrm{P}=0.755)$.

$20 \%$ of adenoviral, $13.5 \%$ of rota virus and $33.3 \%$ of bi-infection, none of Human Boca virus presented with neurologic signs without significant differences $(\mathrm{P}=0.619)$.

There was no significant association between neurological symptoms with age, sex, virus type, and attending time $(\mathrm{P}>0.05)$.

\section{Discussion}

In this is prospective study, we try to find the cause of communityacquired acute viral gastroenteritis in a hospital admitted children in an educational century in Tehran, Iran. Unknown causes for viral gastroenteritis in present study was $12 \%(6 / 50)$.

Rotavirus infection $(48 \%$; 24/50) was the most common cause of viral etiology in present study. Adenovirus $(20 \%, 10 / 50)$ co-infection (Adeno \& Rota virus was 6\% (3/50), Human Boca virus $(8 \%, 4 / 50)$ respectively.

Human Boca virus was significantly lower than Adeno \& Rota virus ( $\mathrm{p}=0.0001) .16 \%$ of cases with viral AGE had neurological symptoms. The most common of neurologic presentation was seizure $(12 \%)$; aseptic meningitis was rare $(4 \%)$ with non-significant difference in mean age between cases $(\mathrm{P}=0.755)$

Acute gastroenteritis is one of the causeof morbidity and mortality in Iranian children childhood in developing countries and Iran. The presence of $\mathrm{HBoV}$ genomic DNA in stool samples from children with AGE reported in other countries eg China, Australia, USA and Brazil.

Our results are very close to Vicente et al. study; $\mathrm{HBoV}$-DNA detected just in stool samples of $6 \%$ of cases. None of the HBoV-positive patients reported respiratory symptoms. One study in Brazil, reported the positive $\mathrm{HBoV}$ (PCR) in \%2 (705 diarrhea stool samples) [8]. Lau et al. study determined HBoVin 30 (2.1\%) of 1435 fecal samples. Fever and watery diarrhea were the most common symptoms. Co-detection with other pathogens occurred in 33\% and $56 \%$ of respiratory and fecal samples, with minimal sequence variations [14].

\section{Conclusion}

This study indicated that viral agents, especially rota virus can be obtained from near $60 \%$ of studied cases. Adenovirus (20\%); Human Boca virus( $8 \%)$ and other (undiagnosed) viral infection was less common causes. Neurological symptoms including seizure or aseptic meningitis might observe in $16 \%$ of children with acute onset of acute viral GE especially co-infection rota and adenoviral infection (33.3\%) which is not related to age, sex and attending time. Rotavirus-associated encephalopathy described by some authors. Due to presence a safe and effective rotavirus vaccination, we prefer to routine usage of it as a public health priority in Iran. Further study is required to determine the role of rotavirus and other viral infection in diarrhea associated encephalopathy.

\section{References}

1. Elliott EJ (2007) Acute gastroenteritis in children. BMJ 334: 35-40.

2. Curns AT, Steiner CA, Barrett M, Hunter K, Wilson E, et al. (2010) Reduction in acute gastroenteritis hospitalizations among US children after introduction of rotavirus vaccine: analysis of hospital discharge data from 18 US states. $J$ Infect Dis 201: 1617-1624.

3. Lynch M, Lee B, Azimi P, Gentsch J, Glaser C, et al. (2001) Rotavirus and central nervous system symptoms: cause or contaminant? Case reports and review. Clin Infect Dis 33: 932-938.

4. Abe T, Kobayashi M, Araki K, Kodama H, Fujita Y, et al. (2000) Infantile convulsions with mild gastroenteritis. Brain Dev 22: 301-306.

5. Weinstein $M(2006)$ Seizures and encephalopathy as the presenting sign of viral gastroenteritis. Pediatr Emerg Care 22: 579-581.

6. Iturriza-Gómara M, Auchterlonie IA, Zaw W, Molyneaux P, Desselberger U, et al. (2002) Rotavirus gastroenteritis and central nervous system (CNS) infection: characterization of the VP7 and VP4 genes of rotavirus strains isolated from paired fecal and cerebrospinal fluid samples from a child with CNS disease. $J$ Clin Microbiol 40: 4797-4799.

7. Nakagomi T, Nakagomi O (2005) Rotavirus antigenemia in children with encephalopathy accompanied by rotavirus gastroenteritis. Arch Virol 150: 1927-1931.

8. Albuquerque MC, Rocha LN, Benati FJ, Soares CC, Maranhão AG, et al. (2007) Human bocavirus infection in children with gastroenteritis, Brazil. Emerg Infect Dis 13: 1756-1758

9. Arnold JC, Singh KK, Spector SA, Sawyer MH (2006) Human bocavirus: prevalence and clinical spectrum at a children's hospital. Clin Infect Dis 43 283-288.

10. Lee JI, Chung JY, Han TH, Song MO, Hwang ES (2007) Detection of human bocavirus in children hospitalized because of acute gastroenteritis. J Infect Dis 196: 994-997.

11. Manning A, Russell V, Eastick K, Leadbetter GH, Hallam N, et al. (2006) Epidemiological profile and clinical associations of human bocavirus and other human parvoviruses. J Infect Dis 194: 1283-1290.

12. Kesebir D, Vazquez M, Weibel C, Shapiro ED, Ferguson D, et al. (2006) Human bocavirus infection in young children in the United States: molecula 
Citation: Noorbakhsh S, Monavari HR, Tabatabaei A (2013) Neurological Manifestaions in Acute Onset of Viral Gastroentritis. J AIDS Clin Res 4: 189. doi:10.4172/2155-6113.1000189

epidemiological profile and clinical characteristics of a newly emerging respiratory virus. J Infect Dis 194: 1276-1282.

13. Bastien N, Brandt K, Dust K, Ward D, Li Y (2006) Human Bocavirus infection, Canada. Emerg Infect Dis 12: 848-850.

14. Lau SK, Yip CC, Que TL, Lee RA, Au-Yeung RK, et al. (2007) Clinical and Molecular Epidemiology of Human Bocavirus in Respiratory and Fecal Samples from Children in Hong Kong. J Infect Dis 196: 986-993.

15. Kermani NA, Jafari F, Mojarad HN, Hoseinkhan N, Zali R (2010) Prevalence and associated factors of persistent diarrhoea in Iranian children admitted to a paediatric hospital. East Mediterr Health J 16: 831-836.

16. Jafari F, Garcia-Gil LJ, Salmanzadeh-Ahrabi S, Shokrzadeh L, Aslani MM, et al. (2009) Diagnosis and prevalence of enteropathogenic bacteria in children less than 5 years of age with acute diarrhea in Tehran children's hospitals. $J$ Infect 58: 21-27
17. Zarnani AH, Modarres Sh, Jadali F, Sabahi F, Moazzeni SM, et al. (2004) Role of rotaviruses in children with acute diarrhea in Tehran, Iran. J Clin Virol 29: 189-193.

18. Kazemi A, Tabatabaie F, Agha-Ghazvini MR, Kelishadi R (2006) The Role of Rotavirus in Acute Pediatric Diarrhea in Isfahan, Iran. Pak J Med Sci 22: 282-285.

19. Eesteghamati A, Gouya M, Keshtkar A, Najafi L, Zali MR, et al. (2009) Sentine Hospital-Based Surveillance of Rotavirus Diarrhea in Iran. J Infect Dis 200 S244-S247.

20. Saderi H, Roustai MH, Sabahi F, Sadeghizadeh M, Owlia P, et al. (2002) Incidence of enteric adenovirus gastroenteritis in Iranian children. J Clin Viro 24: $1-5$.

21. Modarres S, Jam-Afzon F, Modarres S (2006) Enteric Adenovirus Infection In Infants And Young Children With Acute Gastroenteritis In Tehran. Acta Medica Iranica 44: 349-353. 